\title{
APLICAÇÃO DE TÉCNICAS DE GESTÃO DE PROJETOS NO DESENVOLVIMENTO E APRIMORAMENTO DE UM FESTIVAL MULTICULTURAL ALTERNATIVO SEM FINS LUCRATIVOS NO BRASIL
}

\section{APPLICATION OF PROJECT MANAGEMENT TECHNIQUES IN THE DEVELOPMENT AND ENHANCEMENT OF AN ALTERNATIVE MULTICULTURAL FESTIVAL WITHOUT PROFIT IN BRAZIL}

\author{
Vinícius Schmitt* E-mail: vinicius0schmitt@gmail.com \\ *Universidade Metodista do Sul (IPA), Porto Alegre, RS
}

Resumo: Devido à crescente expansão do cenário cultural independente no Brasil, surgem, a cada dia, diferentes formas de expressar e representar essas demandas que brotam no âmago da sociedade, ramificando-se em diversos expoentes, dentre os quais, existem os festivais multiculturais. O meio da contracultura não tem como objetivo principal a geração de lucro, devido a esta característica, configura-se uma deficiência de gestão, onde controle e planejamento não são tidos como fatores críticos no desenvolvimento destes festivais. O objetivo desta pesquisa visa identificar as melhores técnicas para aplicação na gestão de projetos para o desenvolvimento e aprimoramento de um festival multicultural alternativo sem fins lucrativos. Este estudo foi ambientado na busca desta meta através da imersão real no desenvolvimento e acompanhamento de dois festivais no estado do Rio Grande do Sul, assim como a aplicação e interpretação de um questionário respondido por 60 organizadores de diversos festivais em todo o território Brasileiro. Foi possível delinear o perfil de gestão nos festivais multiculturais, assim como seus desafios internos e externos. Apesar de enfrentar dificuldades iniciais, o objetivo foi alcançado e a aplicação das ferramentas nos festivais acompanhados obteve grande êxito com resultados altamente positivos e ganhos para os organizadores, aumentando a qualidade, controle e autonomia quanto a produção dos eventos.

Palavras-chave: Festival multicultural. Técnicas de gestão de projetos. Projeto e desenvolvimento de serviços. Contracultura. Sem fins lucrativos.

\begin{abstract}
Due to the increasing expansion of the independent cultural scene in Brazil, different forms of expressing and representing these demands that emerge at the heart of the society appear every day, branching out in several exponents, among which there are multicultural festivals. The counterculture does not have as its main objective the generation of profit, due to this characteristic, it is a deficiency of management, where control and planning are not considered as critical factors in the development of these festivals. The objective of this research is to identify the best techniques for application in the project management for the development and improvement of an alternative nonprofit multicultural festival. This study was set in the pursuit of this goal through the real immersion in the development and monitoring of two festivals in the state of Rio Grande do Sul, as well as the application and interpretation of a questionnaire answered by 60 organizers of various festivals throughout the Brazilian territory. It was possible to delineate the management profile at multicultural festivals, as well as its internal and external challenges. Although faced with initial difficulties, the goal was achieved and the application of the tools in the festivals followed was a great success with highly positive results and gains for the organizers, increasing the quality, control and autonomy regarding the production of the events.
\end{abstract}

Keywords: Multicultural festival. Project management techniques. Project and development of services. Counterculture. Non-profit. 


\section{INTRODUÇÃO}

O cenário cultural Nacional Brasileiro tem se transformado nas últimas décadas, sendo que foi observado uma expansão significativa nas iniciativas independentes que não visam como objetivo principal a geração de capital financeiro. Essa expansão deve-se em grande parte, a uma demanda que não é atendida pela produção mainstream ${ }^{1}$, com foco exclusivo no mercado de consumo.

A maior tendência baseia-se na cultura de massa, onde se produz com o objetivo de vender, entretanto quando se está falando de bens de consumo ou serviços não há ônus e sim vantagens financeiras, mas ao aplicar esta metodologia na produção cultural em geral, perde-se sua essência, qualidade e valor intelectual.

Este cenário cultural independente é fomentado por incentivos financeiros que dependem, basicamente, da realização de projetos. Historicamente falando, sempre existiram editais específicos e abrangentes, em todas as esferas públicas, sendo organizados e patrocinados por Secretarias de Cultura, que utilizam diferentes fundos monetários ou métodos de captação de recursos. Segundo o Ministério da Cultura (2016, paginação irregular), Em Julho de 1986 foi sancionada a primeira lei de incentivo a cultura no Brasil (Lei no 7.505), vindo somente em Dezembro de 1991 a criação da Lei de Incentivo a Cultura (Lei o 8.313/91), mais popularmente conhecida como Lei Rouanet, ainda vigente. Seu objetivo é estimular o incentivo cultural através da captação de recursos provenientes da iniciativa privada, criando um mecanismo que permite a dedução do montante fornecido no imposto de renda devido. O Ministério da Cultura (2016, paginação irregular) ainda explica que "o Governo Federal oferece uma ferramenta para que a sociedade possa decidir aplicar, e como aplicar, parte do dinheiro de seus impostos em ações culturais".

A potência e necessidade da cultura independente no Brasil vai muito além do que o estado e mercado têm condições de prover, fazendo com que a sociedade, carente de assistência, busque e crie formas sustentáveis e colaborativas para atingir seus objetivos.

No mundo atual, altamente globalizado e com amplo acesso a tecnologias e ferramentas digitais, torna-se possível organizar, produzir e divulgar iniciativas sem

\footnotetext{
${ }^{1}$ Mainstream é um conceito que expressa uma tendência ou moda principal dominante. A tradução literal de mainstream é corrente ou fluxo principal. (DICIO, 2016, paginação irregular)
} 
apoio direto do estado ou de patrocinadores da iniciativa privada. Isto permite que cooperativas, comunidades ou pequenos grupos consigam obter sucesso em seus nichos culturais.

Devido à crescente expansão do cenário cultural independente no Brasil, surgem, a cada dia, diferentes formas de expressar e representar essas demandas que brotam no âmago da sociedade, ramificando-se em diversos expoentes, dentre os quais, existem os festivais multiculturais alternativos sem fins lucrativos. Estes festivais têm duração mínima de dois dias, possuem três palcos ou mais, sendo que funcionam 24 horas por dia sem parar, apresentando bandas, DJ's, cinema, teatro, oficinas, vivências, debates, tudo que é necessário para receber esta denominação. Podem ser focados em alguma vertente artística, mas exibirão outras e são organizados, apresentados e frequentados, na sua grande maioria, por integrantes da chamada contracultura.

O meio da contracultura ou underground ${ }^{2}$, não tem como objetivo principal a geração de lucro, não se produz para vender, ou seja, não segue os preceitos da economia de mercado. Normalmente os propósitos que o movem e inspiram são referentes à passagem de valores, informações, experiências e conhecimentos, desenvolvimento, revolução e expressão da arte. Devido a estas características, normalmente identifica-se deficiência na gestão, onde controle e planejamento não são tidos como fatores críticos no desenvolvimento dos festivais.

Além de se estar numa era avançada tecnologicamente, também estão ocorrendo avanços no campo das políticas sociais, muitos dos antigos tabus e preconceitos, estão sendo, pouco a pouco, derrubados e substituídos por novos conceitos libertários e inclusivos. Esta nova realidade tem aberto os caminhos de comunicação entre gestores governamentais e componentes da contracultura, criando um diálogo aberto e construtivo, gerando oportunidades antes distantes ou inalcançáveis.

Uma vez que estes festivais ocorrem em locais amplos, que movimentam muitos participantes para a sede dos municípios, é necessário uma estrutura que permita sua execução. Logo, cada vez mais, mostra-se indispensável o diálogo dos

\footnotetext{
2 Underground é utilizado para denominar uma cultura que foge dos padrões normais e conhecidos pela sociedade. Não segue modismos e geralmente não está na mídia. (DICIO, 2016, paginação irregular)
} 
organizadores com as prefeituras e secretarias específicas para que seja possível realizar o evento de forma construtiva, e para isto é necessário que os idealizadores apresentem propostas qualificadas e dignas do recebimento dos recursos municipais.

A justificativa para a pesquisa baseia-se no fato de que o planejamento e execução de um festival demandam uma quantidade significativa de recursos humanos e financeiros, considerando um evento sem fins lucrativos, torna-se necessário executar as tarefas de maneira mais eficiente e menos onerosa possível, agregando qualidade e diversidade. Da mesma forma, é preciso haver consistência e valor cultural na proposta, possibilitando que os órgãos públicos e os empreendedores tenham interesse, permitindo a captação dos recursos.

Conforme o governo cria mecanismos para facilitar o incentivo à cultura, é natural que seja necessário profissionalizar cada vez mais o desenvolvimento destes festivais, tanto pela crescente oportunidade quanto pela diferenciação e destaque em relação aos demais eventos. Em 2014, foi criada a Política Nacional de Cultura Viva que:

[...] atende iniciativas dos mais diversos segmentos da cultura: cultura de base comunitárias, com ampla incidência no segmento da juventude, Pontos de Cultura Indígenas, Quilombolas, de Matriz Africana, a produção cultural urbana, a cultura popular, abrangendo todos os tipos de linguagem artística e cultural. (CULTURA VIVA, 2016, paginação irregular).

Com o aumento do número de festivais sendo realizados e de eventos em geral, a gestão se tornou uma área que tem registrado significativa expansão. Devido à maior quantidade e complexidade, pode-se ter Engenheiros de Produção atuando neste segmento. Inclusive já existem diversos cursos e tecnólogos consolidados especializados na área sendo oferecidos em universidades e instituições de renome.

No Brasil, já existem duas grandes organizações, com larga abrangência e em expansão. A ABRAFESTA (Associação Brasileira de Eventos Sociais), fundada em 2009, que é responsável por representar os interesses do setor de eventos e festas. e que em 2013, lançou o Manual de Boas Práticas em Eventos (ABRAFESTA, 2016). A outra é a ABEOC (Associação Brasileira de Empresas de Eventos), fundada em 1997, que tem buscado o desenvolvimento, normatização, padronização e regulamentação do setor no país, e que atualmente possui Revista Produção Online. Florianópolis, SC, v. 20, n. 4, p. 1088-1125, 2020. 
representação em 12 estados Brasileiros, mas que, conforme o seu planejamento estratégico visa, até 2020, possuir representação em todos estados da nação (ABEOC, 2016).

Como o pesquisador é organizador e idealizador de um festival em moldes similares e busca desenvolver o potencial existente, assim como migrar a plataforma para um formato que receba subsídio de programas governamentais, apoio das prefeituras, focando no empreendedorismo social como ação transformadora do ambiente, esta pesquisa busca auxiliar na complementação das metas e na evolução dos festivais multiculturais alternativos sem fins lucrativos, criando um diferencial que permita buscar recursos de financiamentos.

O objetivo desta pesquisa visa identificar as melhores técnicas para aplicação na gestão de projetos para o desenvolvimento e aprimoramento de um festival multicultural alternativo sem fins lucrativos.

Este artigo está dividido em mais quatro seções, sendo a próxima onde estão presentes os fundamentos teóricos abordados e aplicados, assim como as ferramentas e conceitos de gestão. Segue-se para as metodologias utilizadas e delimitações, adentrando nos resultados e considerações, e finalmente trazendo as conclusões obtidas.

\section{DESENVOLVIMENTO}

A fundamentação apresenta definições, conceitos e metodologias a respeito da gestão de projetos focada no cenário de desenvolvimento de novos produtos e serviços, concentrando-se nos aspectos com potencial de aplicabilidade na gestão de festivais multiculturais, bem como os temas relacionados aos aspectos da responsabilidade social e gestão ambiental nas dinâmicas organizacionais, que vão ao encontro direto do conceito do empreendedorismo social com foco na sustentabilidade.

\subsection{Projeto}

A metodologia de projeto tem grande valia para a realização de qualquer atividade planejada com antecedência, ele contém o mapa com o necessário para o Revista Produção Online. Florianópolis, SC, v. 20, n. 4, p. 1088-1125, 2020. 
planejamento, execução e controle da ação desejada. A melhor forma de prever as possíveis situações e organizar-se para definir e realizar o proposto, obtendo melhor controle que acarretará em qualidade e menores custos.

Conforme o PMI (2013, p. 3), projeto é "um esforço temporário empreendido para criar um produto, serviço ou resultado único." Ainda, o PMI (2013) comenta que as atividades envolvidas em um projeto podem ser novas para os responsáveis por realizá-lo, sendo necessária maior dedicação no planejamento por não se tratar de trabalho rotineiro. Para Martins (2007):

Genericamente "projeto" significa "empreendimento", e como tal é um trabalho que visa a criação de um produto ou a execução de um serviço específico, temporário, não repetitivo e que envolve um certo grau de incerteza na realização. (MARTINS, 2007, p. 4).

\subsubsection{Processos de gerenciamento de projetos}

Todo projeto que nasce deverá ser gerenciado, atingindo todos os aspectos que podem ser relacionados ao seu planejamento, execução e controle. Para obter o melhor resultado possível, caberá à equipe encontrar as melhores maneiras de subdividir para então gerenciar. Conforme o PMI (2013, p. 47), "um processo é um conjunto de ações e atividades inter-relacionadas que são executadas para criar um produto, serviço ou resultado pré-especificado."

Figura 1 - Grupos de processos de gerenciamento de projetos

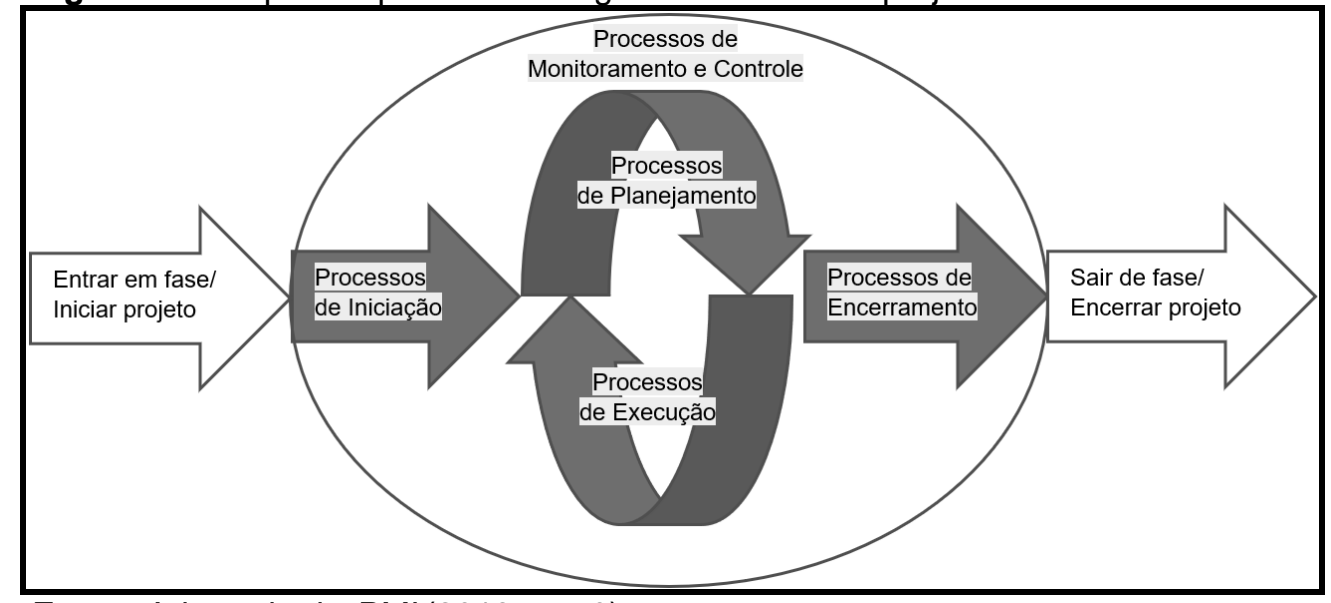

Fonte: Adaptado de $P M I(2013$, p. 50). 
Os processos terão por característica compositiva, entradas, ferramentas e técnicas que serão aplicadas para transformar estas entradas nas respectivas saídas. Na Figura 1 são apresentados os grupos de processos que permitem o gerenciamento de projetos.

\subsubsection{Definição de atividades}

Conforme o escopo é definido, surge a necessidade de definir as atividades para realização de cada entrega, sendo que o $P M I(2013$, p. 149) diz que "definir as atividades é o processo de identificação e documentação das ações específicas a serem realizadas para produzir as entregas do projeto", logo, se pode dividir os pacotes de trabalho em atividades que irão fornecer a base para estimar, programar, executar, monitorar e controlar o projeto.

\subsubsection{Ferramentas e técnicas para definição das atividades}

As atividades devem ser definidas visando um fácil entendimento, mensuração e controle, sendo que o PMI (2013) sugere que se utilize as técnicas de decomposição, planejamento em ondas sucessivas e opinião especializada para definição das atividades.

\subsubsection{Estimativa de custos}

Todo projeto deve ter seus custos controlados, é impossível realizar uma atividade sem ser capaz de estimar seu valor, considerando o cenário de um evento sem fins lucrativos, apresenta-se como uma ferramenta chave para o sucesso ou não do empreendimento. A capacidade e assertividade na estimativa de custos representará um grande diferencial para o projeto. Quando os recursos são limitados e contas devem ser prestadas, quanto mais preciso for o levantamento, maiores serão as chances de obtenção de capital através de financiamento por terceiros.

Para o PMI (2013), as entradas para realização da estimativa são tão importantes quanto à mesma, pois a qualidade e precisão dos valores serão 
afetadas diretamente pelo nível de detalhamento e realidade das informações que a alimentam.

\subsubsection{Ferramentas e técnicas para estimativa de custos}

Sendo de vital importância para a sobrevivência do projeto, os custos também devem ser estimados através da utilização de diversas técnicas de comprovada

eficácia. É principalmente nesta etapa que se torna necessário utilizar uma metodologia clara e concisa, capaz de fornecer valores reais e práticos.

As técnicas sugeridas pelo PMI (2013) são: Opinião especializada, estimativa análoga, estimativa paramétrica, estimativa bottom-up, estimativa de três pontos, análise de reservas, custo da qualidade, software de gerenciamento de projetos, análise de proposta do fornecedor e técnicas de tomada de decisão em grupo.

\subsubsection{Gerenciamento de recursos humanos}

A realização de um projeto sempre evolverá recursos humanos, logo é importante compreender como organizar corretamente, obtendo compreensão clara de todos membros da equipe a respeito das funções, responsabilidades, competências e autoridades. A criação e separação de cargos, atrelados as suas características, irá auxiliar no bom andamento e sucesso do projeto, pois ficará claro quem é responsável pelo que e a quem deverá se reportar ou cobrar os resultados.

Quanto mais simples o projeto, mais importante é definir e deixar claro para a equipe todos estes aspectos, pois evitará que alguma etapa fique descoberta ou que mais de uma pessoa trabalhe na mesma tarefa, gerando conflito de interesses ou competição de recursos.

Das atividades necessárias a serem realizadas para um bom gerenciamento de recursos humanos, o PMI (2013) cita papéis e responsabilidades, organograma hierárquico, gráficos Matriciais e networking, sendo as mesmas apresentadas na Figura 2. 


\section{Figura 2 - Formatos de definição dos papéis e responsabilidade}

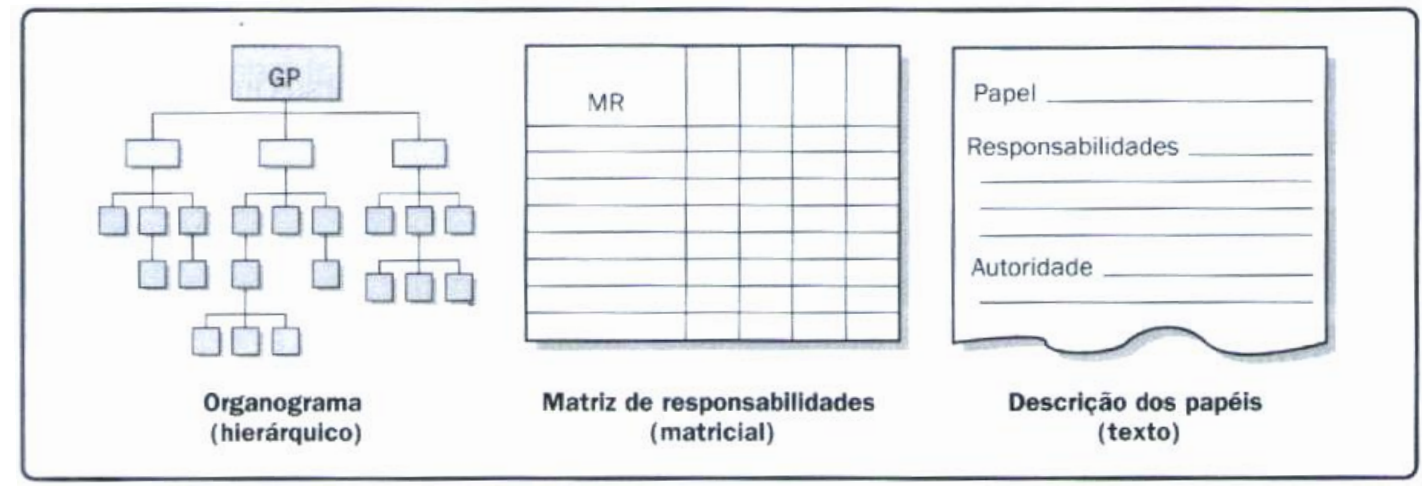

Fonte: PMI (2013, p. 261).

\subsubsection{Influências culturais}

Toda e qualquer forma de organização sempre será influenciada conforme a sua constituição humana. É a partir dela e de seus colaboradores, que serão experimentadas e criadas as formas de executar seus procedimentos, caracterizando sua cultura, muitas vezes única. O ambiente e seus integrantes serão responsáveis por refletir no empreendimento, os valores e objetivos do mesmo.

Considerando esta configuração, o PMI (2013, p. 20), diz que "a cultura e o estilo da organização afetam a maneira como ela conduz os projetos. Culturas e estilos são fenômenos de grupo conhecidos como normas culturais, que se desenvolvem ao longo do tempo.".

Deve-se compreender que grande parte das ferramentas e inovações na área de gestão de projetos foram realizadas visando o ambiente empresarial localizado no universo da iniciativa privada mercadológica, com objetivos de geração de lucro. São ambientes de maior formalidade e com intenções voltadas para 0 desenvolvimento do negócio, tendo apenas em segundo plano, ou devido à necessidade legal, o desenvolvimento social. Neste ponto existe a grande barreira a ser ultrapassada, adaptar conceitos idealizados na cultura do empreendedorismo capital para o empreendedorismo social e remodelar algumas características geradas a partir do ambiente.

\subsection{Gestão do processo de desenvolvimento de serviços}

A área de gestão de projetos encontra-se bem desenvolvida, possui uma vasta gama de ferramentas criadas e aplicadas com muitos anos e cases 
confirmando sua eficácia, e é provida de alta diversidade e qualidade de literatura disponível. O mesmo não se aplica a área de gestão do processo de desenvolvimento de serviços, apesar de compreender um negócio, o fornecimento de um serviço caracteriza-se de forma bem diferente se comparado a um produto.

Para Silvestro, Fitzgerald e Johnston (1992), a principal dificuldade para desenvolver metodologias que compreendam o planejamento e desenvolvimento de serviços encontra-se na sua característica de intangibilidade, tornando o processo mais complexo se comparado ao desenvolvimento de produtos.

Definir o que é serviço não é uma tarefa fácil, devido à grande gama do setor, onde existem muitas variações e definições. Cook, Goh e Chung (1990) comentam que não há uma simples definição para serviço capaz de englobar todas as características e conceitos complexos que o acompanham.

\subsubsection{Modelo de desenvolvimento de serviço}

Com o intuito de aplicar os conhecimentos referentes aos processos identificados e atender as necessidades de ser objetivo e preciso, basear-se em fatos e possuir metodologia estruturada, Mello (2010) criou um modelo para desenvolvimento de serviços (Figura 3).

Figura 3 - Modelo proposto para o projeto e desenvolvimento de serviços

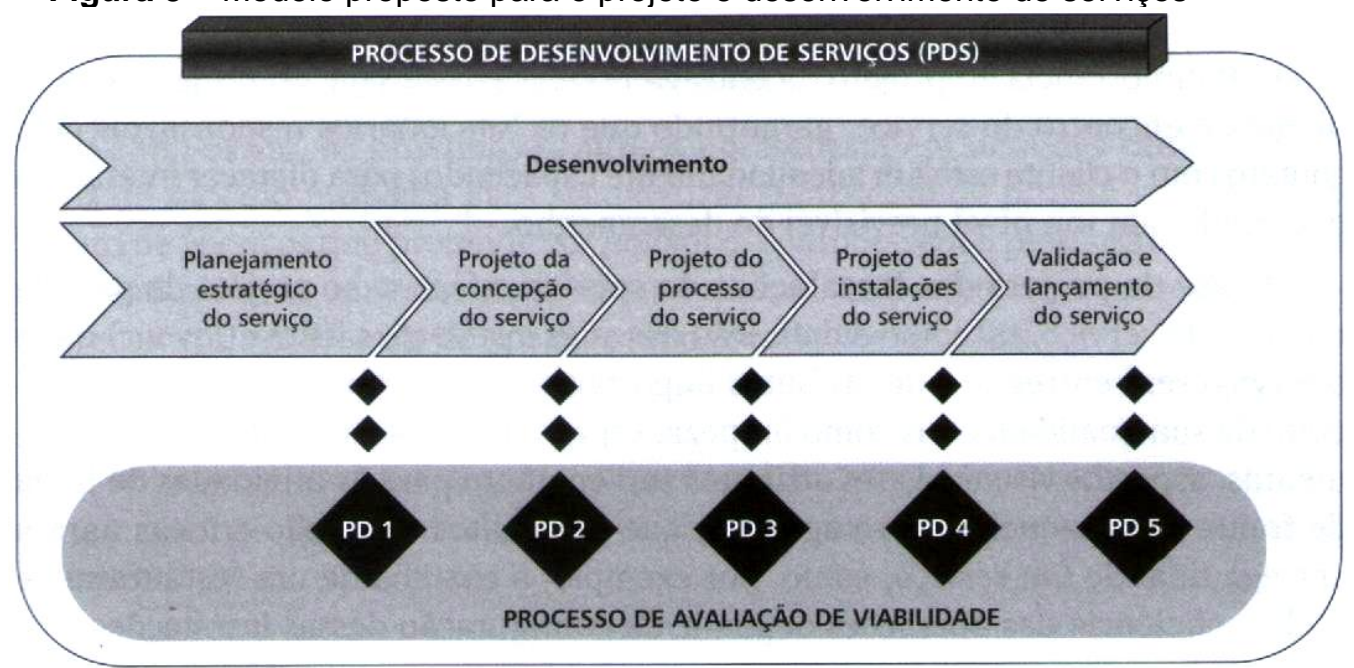

Fonte: Mello (2010, p. 95). 
O modelo de Mello (2010) é dividido em cinco fases:

- Planejamento estratégico do Serviço: Refere-se à pesquisa das necessidades e expectativas dos clientes para a criação ou melhoria de um serviço que atenda as necessidades e expectativas. Trata, também, da etapa de monitoramento do mercado, do serviço e da tecnologia;

- Projeto da concepção do serviço: Refere-se às ideias geradas para sanar as necessidades e expectativas prospectadas, que devem ser selecionadas e, com o apoio de uma estratégia competitiva adequada para o mercado, define o conceito e o pacote de serviço a serem ofertados;

- Projeto do processo do serviço: Refere-se à identificação e definição dos principais processos e as atividades necessárias para a realização, entrega ou manutenção do serviço. Os processos e atividades que integram uma operação são aqueles necessários para que o serviço entregue seu resultado, inclusive os relativos à interação entre o provedor e o cliente;

- Projeto das instalações do serviço: Refere-se ao projeto da parcela tangível do serviço, tal como a definição das instalações físicas onde o serviço será entregue e de atributos importantes na percepção do cliente a respeito da qualidade;

- Validação e lançamento do serviço: Refere-se à definição do processo que garanta que o serviço projetado realmente atenda ao que foi identificado como necessidade na fase de planejamento estratégico. Essa fase prevê a definição de uma sistemática para avaliação do serviço projetado e sua posterior validação pelo cliente.

\subsection{Sustentabilidade e responsabilidade social}

Albuquerque (2009), expões que, para transformar nosso meio de vida, trazer a mudança, modificar os valores e conceitos, quebrar os paradigmas, desenvolverse e evoluir de forma simbiótica e orgânica, é imprescindível que se busque maneiras de desvincular-se dos modelos empreendedores das economias de mercado. Não existe mais espaço para iniciativas que tem por objetivo apenas sugar recursos e obter vantagens através de relações parasitárias com o meio ambiente e sociedade. O planeta Terra não será capaz de continuar dando suporte à vida se os 
seres humanos persistirem em negligenciar os efeitos causados pelo desenvolvimento exponencial sem limites.

\subsubsection{Sustentabilidade}

A gestão ambiental e responsabilidade social são fatores preponderantemente necessários para fomentar iniciativas com foco pró-ambiental e de cunho desenvolvimentista social. $O$ caminho da sustentabilidade percorre diretamente e através destes conceitos fundamentalistas.

Clemente (2008), explica que, atuar de formar sustentável envolve todos os aspectos relacionados com a atividade proposta pelo empreendedor, ser sustentável não é uma estratégia de marketing, nem uma abordagem para reduzir custos, ser sustentável é inserir seus conceitos e valores na alma do projeto. Significa enfrentar diversas barreiras e nadar contra a corrente, precisa ser uma escolha definitiva, um objetivo e uma inspiração propulsora, assumida por todas as partes interessadas.

\subsubsection{Dimensões da sustentabilidade}

Para que seja possível praticar e desenvolver a sustentabilidade, é necessária a criação de limites contextuais, estes limites servem para embasar e guiar as formas e ambientes de atuação relacionando as práticas entre si.

A criação da ideia de sustentabilidade então se referência a três esferas básicas interconectadas pela prática sustentável, sendo estas as chamadas dimensões da sustentabilidade, que, conforme Albuquerque (2009) são a econômica, ambiental e social e estão representadas na Figura 4.

O principal entendimento baseia-se na concepção que se vive em um planeta de recursos finitos, mas da mesma maneira, existem diversas interações ambientais e sociais, devendo compreender e promover, antes de qualquer coisa, a evolução sustentável de todo o meio, não havendo espaços para posicionar o ser humano acima das demais espécies e como dono do planeta Terra e tudo que nele existe. 


\section{Figura 4 - Dimensões da sustentabilidade (Triple Bottom Line)}

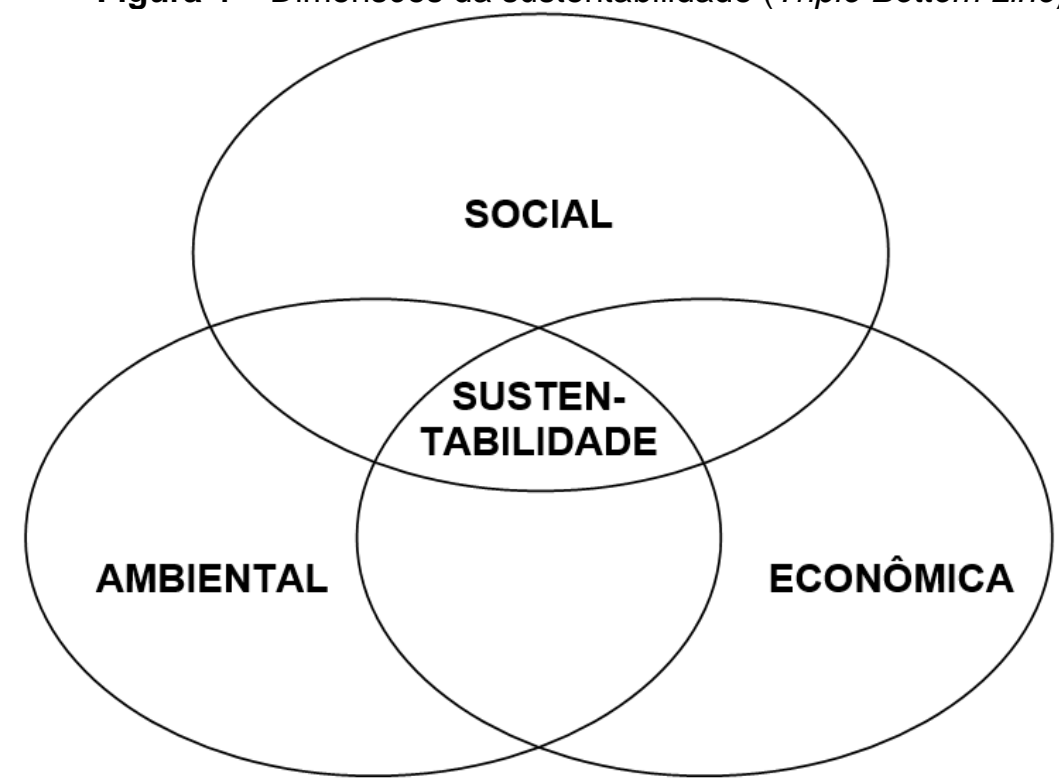

Fonte: Adaptado de Albuquerque (2009, p. 220).

- Dimensão econômica: Esta dimensão deve servir aos objetivos que tangem o capital necessário ao desenvolvimento e sobrevivência da organização, deve servir como propulsora e provedora de recursos fomentadores, utilizando-se das maneiras cabíveis e respeitando os preceitos ambientais e sociais. Conforme comentado por Sachs (1993), esta dimensão possibilita alocação e gestão eficiente dos recursos, e fluxo regular dos investimentos públicos e privados. Para a Global Reporting Initiative (2009), refere-se aos impactos da organização sobre as condições econômicas de seus stakeholders e sobre os sistemas econômicos em nível local, nacional e global;

- Dimensão ambiental: Esta dimensão refere-se a todas interações relacionadas com os sistemas vivos e a utilização e gestão responsável dos recursos, assim como sua preservação. Segundo Sachs (1993), deve-se utilizar os recursos renováveis e limitar os recursos não renováveis através do uso dos recursos potenciais de diversos ecossistemas, reduzindo impactos e garantindo as futuras gerações sua disponibilidade.

- Dimensão Social: Engloba as relações da organização com os sistemas sociais em que opera, sua direção norteadora é voltada para o desenvolvimento da sociedade, seus objetivos, decisões e ações devem estar focados em promover o bem-estar social. A prosperidade de uma sociedade está relacionada com as relações econômicas ligadas as relações sociais, 
sendo confiança, reciprocidade e trocas. Outro fator preponderante relativo com o desenvolvimento social é a cultura, representante e indicadora fundamental do quão saudável o meio social encontra-se, sendo a manifestação cultural toda a expressão criada por e através de um nicho social.

\subsubsection{Responsabilidade social}

A ideia de responsabilidade social permeia as corporações desde muito tempo, mas sua aplicação verdadeira e efetiva, assim como a incorporação de seus valores segue em segundo plano, quando não completamente abandonada. Uma empresa deve assimilar o entendimento que sua existência depende diretamente do meio em que se posiciona, das relações que desenvolve, dos serviços que presta, dos colaboradores que contrata e dos recursos que utiliza, tudo isto faz parte do círculo social ao qual está inserida.

A pura e simples geração de riqueza sem considerar os demais fatores torna explícita a irresponsabilidade social comumente vista nas economias de mercado, esta falta de consciência não fere somente os envolvidos nas relações diretas, mas representa uma verdadeira afronta à nação global que partilha igualmente todos os recursos, assim como ao estado que autoriza e incentiva seu funcionamento.

loschpe (2000) apresenta três tipos de empresas no que tange à forma como se relacionam com o meio social, sendo: Empresa unicamente como um negócio, como organização social e como empresa-cidadã.

\subsubsection{Empreendedorismo social e ecológico}

O mundo está lotado de empreendedores nas mais diversas áreas, mas na mesma proporção que se tem esta pluralidade de nichos mercadológicos, se encontram poucos empreendedores com objetivos sociais e ecológicos. A grande massa empreendedora concentra-se apenas na geração e manutenção de capital, sendo indiferentes os meios para obtê-los, assim como as consequências causadas por estas atividades.

Segundo o SEBRAE (2016, paginação irregular) "[...] podemos entender como empreendedor aquele que inicia algo novo, que vê o que ninguém vê, enfim, aquele Revista Produção Online. Florianópolis, SC, v. 20, n. 4, p. 1088-1125, 2020. 
que realiza antes, aquele que sai da área do sonho, do desejo e parte para a ação". O conceito amplo do empreendedorismo serve claramente para descrever a configuração ideal da ideia, mas não é possível sair do sonho e realizá-lo num sistema capitalista sem que seja compreendida a dimensão econômica desta tarefa. É necessário levar em conta o aspecto monetário que irá fomentar a sustentação do empreendimento assim como os meios necessários para obtê-lo.

Albuquerque (2009, p. 276) diz que "Tentar e falhar é no mínimo aprender. Não chegar a tentar é sofrer a perda incalculável do que poderia ter conseguido". Seguindo, Albuquerque (2009) comenta que, sabendo-se então que a atividade empreendedora está ligada diretamente as possibilidades de sucesso e fracasso, o empreendedor social e ecológico não é apenas um aventureiro, mas sim um verdadeiro cidadão responsável e consciente da sociedade e do mundo. $O$ empreendedor social busca, através das ferramentas disponibilizadas, transformar o meio em que vive de forma definitiva e duradoura para melhor, indo muito além das figuras da administração pública. O empreendedor socioambiental é o herói determinado sem super poderes do século XXI.

\subsection{Festival multicultural}

Um festival é um evento com início e fim pré-definidos, com um ciclo de repetição anual ou maior. Ocorre em um local específico ou não, e objetiva a celebração através de uma variedade de atrações de cunho musical, visual, cultural e informacional. Visa utilizar a expressão artística em suas diversas formas como propulsora e realizadora das transformações por ele objetivadas.

Festivais comumente possuem um foco principal, seja música, cinema, teatro, circo, cultura, religião e etc. Em casos de festivais musicais, é normal que possuam um gênero principal e a partir deste possam oferecer outras atrações relacionadas. Eles podem ser públicos ou cobrar entrada, tudo irá depender de quem o faz e com qual objetivo. Um festival de uma cidade não terá custos aos seus participantes, pois pretende oferecer entretenimento e cultura para seus habitantes.

Dentro do universo dos festivais, existem os de grande porte, com alto investimento de capital e objetivo de obter lucro, com atrações voltadas para a cultura de massa. Também, existem festivais menores, que normalmente são 
organizados com o intuito de promover a cultura de menor alcance, a contracultura, que não se encontra nos grandes conglomerados midiáticos. Estes festivais são feitos, em grande parte, com recursos extremamente limitados e escassos, mas tem intenção de unificar e fortalecer sua cena cultural, assim como os artistas nela envolvidos.

Um festival que não possui muitos recursos para ser realizado, utiliza diferentes caminhos para contornar este empecilho, seja aplicando mão de obra voluntária ou agregando mais atrações, aumentando seu leque e por consequência, sua rede de influência e apoio.

\section{METODOLOGIA E DELIMITAÇÃO}

O presente trabalho se caracteriza como uma pesquisa de natureza aplicada, com objetivos focados na pesquisa descritiva, utilizando-se de procedimentos de estudo de caso através de uma abordagem qualitativa.

Foram estudados e acompanhados festivais Brasileiros que estejam em sincronia com o ideal de desenvolvimento socioambiental. Apesar de encontraremse fora da rede mainstream, ainda assim existem diversas iniciativas que ocorrem nestes moldes.

Os festivais movimentam entre cinquenta e duzentos artistas, tendo duração mínima de quarenta e oito horas e envolvem públicos variando entre cem até duas mil pessoas, e ocorrem, normalmente, em locais mais afastados, com maior predominância de natureza ou espaços públicos. Foram observados desde os festivais como um todo, até seus organizadores, artistas e participantes, assim como a implementação de uma abordagem contemplando os demais envolvidos.

Para o estudo, foram caracterizados três tipos de festivais:

- Festival Não-Gratuito com lucro: Nos festivais não-gratuitos com lucro, é feita a venda dos ingressos, que permitem a entrada dos participantes no evento, e visam servir como um meio de obtenção de capital para os organizadores;

- Festival Não-Gratuito sem lucro: Nos festivais não-gratuitos sem lucro, é feita a venda dos ingressos, que permitem a entrada dos participantes no evento, mas visam apenas custear o investimento realizado; 
- Festival Gratuito: Nos festivais gratuitos, não existe nenhuma espécie de cobrança para aqueles que desejam participar, o custo para sua realização é obtido através de patrocínio, seja da iniciativa privada ou verba pública destinada à cultura.

Para que fosse possível guiar a coleta de dados foi utilizada a observação assistemática e foi realizada uma pesquisa em referencial teórico para levantamento dos temas referentes ao aprofundamento em questões de maior complexidade.

Devido a falta de informações a respeito dos festivais multiculturais alternativos no Brasil, foi elaborado um questionário (Apêndice $A$ ) visando focar na obtenção de dados para análise de variáveis e permitindo liberdade direcionada nas questões de interesse. Possui questões semiestruturadas, fechadas e de múltipla escolha, com o intuito de realizar um levantamento de dados que pudesse ser quantificado e interpretado. Este questionário foi respondido por 60 organizadores de diversos festivais, representando uma amostra saudável desta população, pois são eventos da contracultura, esta, que carece muito de iniciativas nestes moldes devido as dificuldades logísticas e financeiras envolvidas, não possuindo uma estimativa ou número oficial destes eventos realizados no Brasil, seja pela ABRAFESTA ou ABEOC, devido a sua natureza informal.

A concepção deste trabalho, caracterizado pelo procedimento onde há o estudo de um caso, ocorre, necessariamente, no que concebe o mesmo. Seguindo no objetivo de encontrar as melhores ferramentas de gestão de projetos para aplicar no desenvolvimento e aprimoramento de um festival multicultural alternativo sem fins lucrativos, este estudo foi ambientado na busca desta meta através da imersão real no desenvolvimento e acompanhamento de dois festivais, que tiveram seus nomes preservados, sendo Alfa e Beta. Foram estudados os processos de organização, controle e execução realizados nestes festivais para o seu desenvolvimento e implementação através da observação assistemática.

O festival acompanhado Alfa já está na sua sexta edição no Rio Grande do Sul e faz parte da maior rede de festivais sincronizados no planeta. Já possui celebrações em mais de 80 países e tem uma plataforma anual temática, funcionando através de uma filiação com taxa de inscrição. Apesar de não definir e oferecer modelos de gestão, formatos do festival e vertentes artísticas ou musicais, sempre é obrigatório converter parte dos valores arrecadados para instituições e realizar a sua comprovação. É caracterizado como não-gratuito sem lucro, com Revista Produção Online. Florianópolis, SC, v. 20, n. 4, p. 1088-1125, 2020. 
média de público entre 500 e 1000 pessoas e seu organizador já está envolvido na área de eventos há cerca de 20 anos, dos quais, 10 anos produzindo festivais.

O festival acompanhado Beta está na sua segunda edição. É caracterizado como não-gratuito sem lucro, com média de público entre 1000 e 2000 pessoas e seu organizador já está envolvido no desenvolvimento de festivais há cerca de 4 anos.

A metodologia estabelecida para trabalhar com os festivais acompanhados foi a de realizar a criação dos mesmos baseado no Modelo de Processo de Desenvolvimento de Serviços (Figura 3), dividindo as tarefas através de Decomposição, Opinião Especializada e Ondas Sucessivas, para então alocá-las nos Grupos de Processos de Gerenciamento de Projetos (Figura 1), realizando a estimativa de custos através da Estimativa bottom-up, Estimativa de três pontos e Análise de reservas. A gestão dos recursos humanos foi feita por Papéis e Responsabilidades, Gráficos Matriciais e Organograma. Também foi desenvolvida uma apresentação e projeto, seguida pela realização de um seminário entre os festivais Alfa e Beta, tendo um apresentado sua proposta e projeto para o outro, buscando simular as dúvidas e questionamentos normalmente feitos pelas prefeituras ou patrocinadores. Para a etapa do pós-evento, foi proposto o desenvolvimento de um questionário direcionado ao público (Apêndice B).

Para que o planejamento e desenvolvimento pudesse ser norteado de forma correta, com um sólido embasamento, foi realizada uma explanação com os organizadores dos festivais Alfa e Beta, a respeito da caracterização do evento como um serviço e seus demais aspectos. A obtenção do melhor de cada ferramenta se deu por realizar as devidas adaptações para a realidade em que estavam sendo aplicadas, assim como o entendimento e compreensão de todos os conceitos envolvidos e trabalhados. Sempre que um tópico foi desenvolvido, foram realizadas explanações teóricas e práticas, buscando facilitar a absorção e internalização do conhecimento pelos organizadores, bem como entenderem o que se estava buscando.

Para que ambos festivais pudessem ser desenvolvidos assumindo uma postura ética e ativa nos meios ambiental e social, foram estudados, trabalhados e praticados, durante todas as etapas, os valores e conceitos de uma empresa-cidadã, comprometida com os pilares que compõem as dimensões da sustentabilidade e atuando através dos ideais do empreendedorismo social e ecológico.

Revista Produção Online. Florianópolis, SC, v. 20, n. 4, p. 1088-1125, 2020. 


\section{RESULTADOS E CONSIDERAÇÕES}

Os resultados e considerações são fruto do acompanhamento de dois festivais, juntamente da aplicação de algumas técnicas em ambos, somando aos resultados adquiridos através das 60 contribuições feitas por organizadores de festivais ao questionário.

Os resultados estão divididos conforme os tópicos que foram abordados. Em cada sessão, são transcorridos e analisados primeiramente os resultados obtidos através do questionário, estando separados pelos gráficos gerados a partir das questões de múltipla escolha e as respostas dadas nas questões semiestruturadas. Posteriormente são discutidos os resultados obtidos nos festivais acompanhados.

\subsection{Caracterização}

A caracterização destes festivais se dá de acordo com a Figura 5, foi observado que a maior parcela não são feitos com objetivo de lucro e sim de apenas fomentar e dar vazão para as diversas expressões da arte, sendo 40\% gratuitos, onde é obrigatório buscar meios de financiamento, seja na iniciativa privada ou verbas da união. A média de público fica na faixa de cem à duas mil pessoas (80\% da amostra) e todos organizadores informaram já ter alguma experiência com um ou mais eventos, inclusive se utilizando destes outros como fonte de renda.

Figura 5 - Caracterização dos eventos

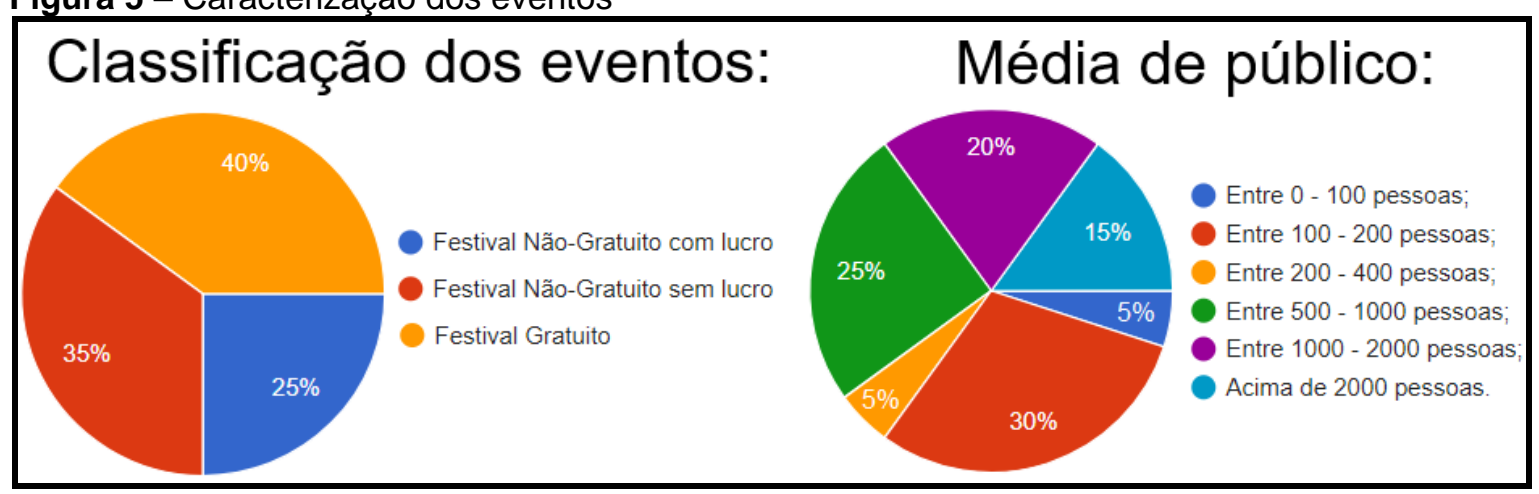

Fonte: Elaborado pelo autor. 


\subsection{Gestão dos recursos humanos}

A questão da gestão dos recursos humanos se provou ser um dos pontos mais delicados e cruciais tanto dos festivais acompanhados, como dos que responderam o questionário. Conforme pode ser observado na Figura 6, apesar de 85\% terem afirmado possuir alguma divisão de cargos com funções, responsabilidades, competências e nível de autoridade, apenas $25 \%$ utilizam algum modelo de gestão. Outro dado interessante, se refere aos $25 \%$ que consideram sua gestão dos recursos humanos apenas atendendo as necessidades mínimas e 55\% afirmam que a gestão de recursos humanos é satisfatória, mas poderia melhorar. Esta área também foi sinalizada pelos organizadores, através do questionário, como tendo uma alta incidência de imprevistos e foi considerada de grande importância a aplicação de algum modelo para sua gestão.

Figura 6 - Dados Gestão de Recursos Humanos

Existe alguma divisão específica de cargos com funções, responsabilidades, competências e nível de autoridade?

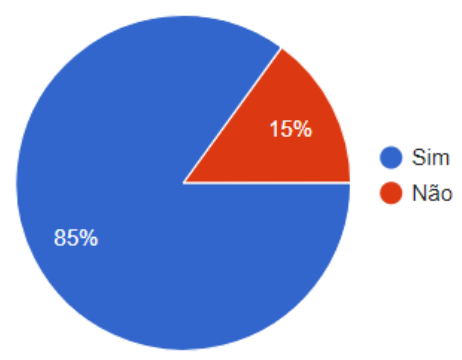

Se utiliza alguma técnica ou modelo reconhecido para gestão de recursos humanos?

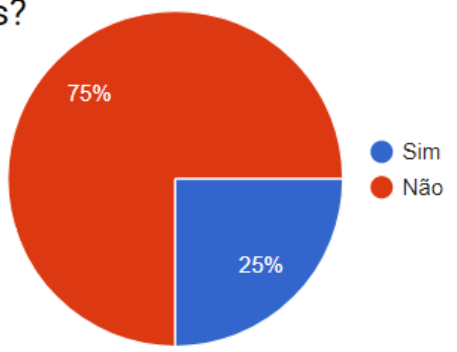

Como você classificaria a gestão dos recursos humanos no seu projeto?

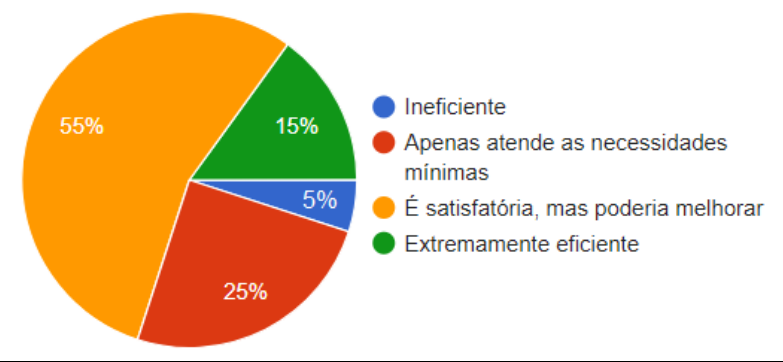

Fonte: Elaborado pelo autor. 
No questionário, os organizadores relataram fazer a criação de funções (responsáveis, facilitadores e voluntários), baseados nos grupos de trabalho oriundos das áreas necessárias para $O$ desenvolvimento dos festivais $\mathrm{e}$ conhecimentos em administração de empresas. A operação se dá de forma autogestionada, mas com as decisões centralizadas para sanar a falta de qualificação no restante da equipe, sendo os níveis de autoridade baseados na experiência de cada integrante. Ressaltaram que demoraram anos adquirindo conhecimento para atingir um bom domínio das demandas em recursos humanos, pois a área de eventos tem uma característica mais informal e a equipe normalmente é formada por amigos, conhecidos e o próprio público, além de ter grande rotatividade em diversas áreas.

Nos festivais acompanhados, apesar de haver divisões de cargos e funções, toda esta informação era verbal e informal, foram aplicadas as ferramentas de Papéis e Responsabilidades, Gráficos Matriciais e Organograma Hierárquico para converter este conhecimento em informação física. Apesar de, inicialmente, considerarem a utilização destes métodos um pouco onerosa, demandando um esforço maior para sua criação, logo nas primeiras semanas verificaram as vantagens de oficializar e documentar estas informações referentes a gestão dos recursos humanos, desenvolvendo autonomia e domínio na criação e atualização dos dados.

\subsection{Estimativa de custos}

A questão da estimativa de custos é uma área que ainda apresenta um grande desafio aos organizadores. Como pode ser visto na Figura 7, apenas $40 \%$ utilizam algum modelo para sua realização, quanto ao englobamento da estimativa, apenas $25 \%$ a consideram ser completa, $55 \%$ consideram parcial e $20 \%$ consideram nula. A estimativa de custos foi considerada apenas atendendo as necessidades mínimas por $35 \%$ dos organizadores e $60 \%$ a consideraram satisfatória, mas podendo melhorar. Estes números ilustram, com clareza, se tratar de um setor que ainda demanda muitas melhorias para atingir níveis de excelência. Esta área foi sinalizada pelos organizadores como sendo de grande importância para a aplicação de algum modelo para sua gestão. 
Figura 7 - Dados Estimativa de Custos

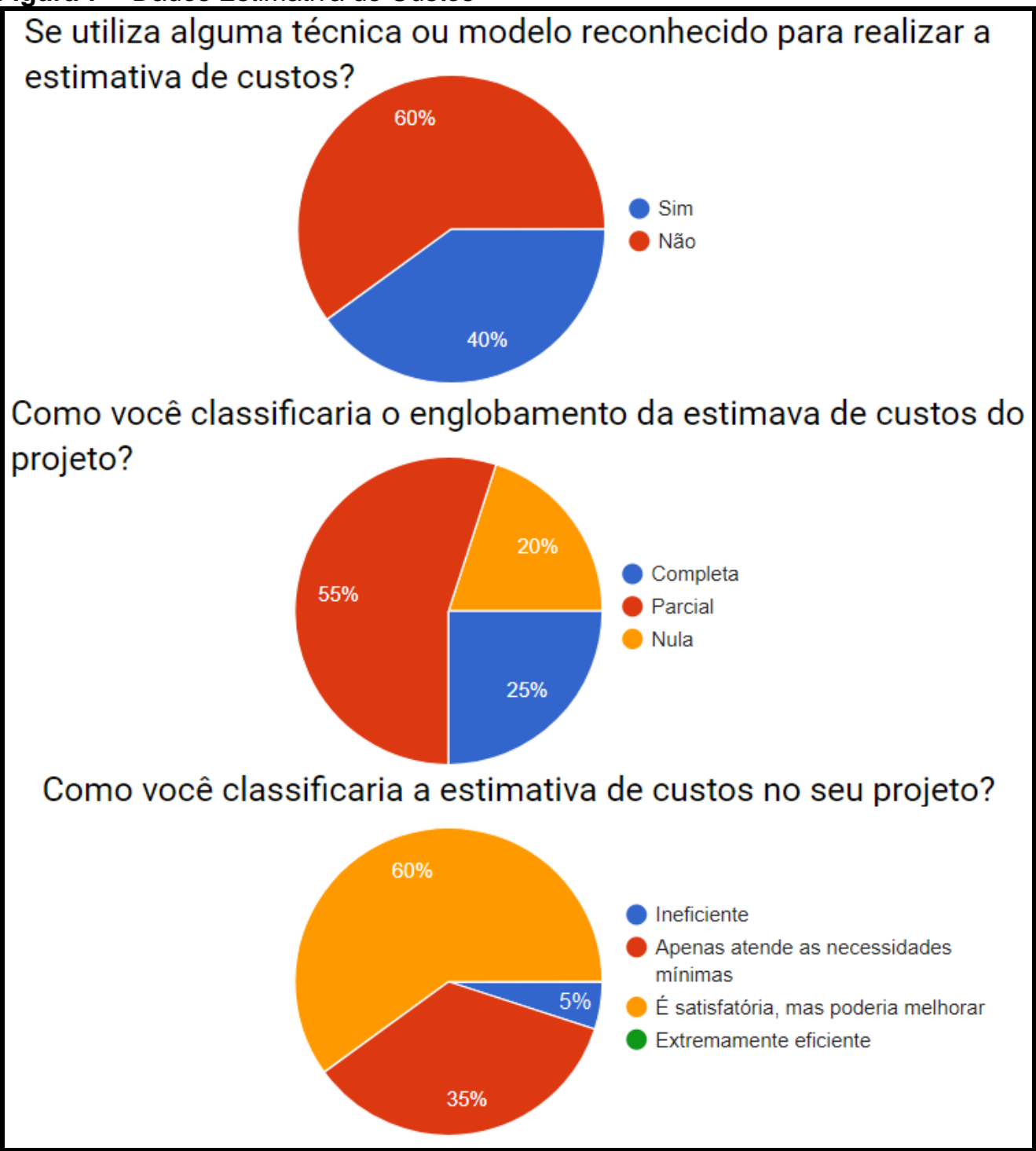

Fonte: Elaborado pelo autor.

No questionário, os organizadores relataram utilizar tabelas para decompor a estimativa de custos por área, definindo tetos acrescidos com margens de segurança. Outra parte importante fica a cargo das projeções para retorno dos investimentos (apenas válida nos festivais não gratuitos), onde se estima qual o público mínimo necessário para custear os valores, considerando também, além do ingresso, seu consumo de bebidas e alimentos. Todo o conhecimento desenvolvido na área de estimativa de custos foi sinalizado fortemente como sendo refinado e aprimorado ao longo das edições.

Nos festivais acompanhados, foram aplicadas as ferramentas de Estimativa bottom-up, Estimativa de três pontos e Análise de reservas para buscar elevar a precisão, qualidade e adaptabilidade dos modelos de estimativa já existentes. Revista Produção Online. Florianópolis, SC, v. 20, n. 4, p. 1088-1125, 2020. 
Devido a experiência nas edições anteriores, ambos já possuíam estimativas sólidas quanto aos valores brutos, mas puderam melhorar muito a qualidade, transparência e detalhamento dos dados, adquirindo uma visão micro e macro da composição dos custos, o que permitiu realocar e distribuir os recursos de forma mais eficiente, garantindo um controle maior, que aumentou a segurança dos organizadores nesta área delicada.

\subsection{Planejamento e desenvolvimento}

O planejamento e desenvolvimento dos festivais funciona de variadas formas, se adaptando as características de cada núcleo organizador. Conforme as respostas do questionário, pode ser observado na Figura 8, que 60\% não utilizam algum modelo na execução do planejamento e desenvolvimento. Apesar de $80 \%$ considerar o planejamento e desenvolvimento satisfatório, mas podendo melhorar, $20 \%$ o consideram apenas atendendo as necessidades mínimas. Esta área foi considerada como tendo um índice relativamente alto de imprevistos, sendo sinalizado pelos organizadores como muito importante aplicar um modelo de planejamento e desenvolvimento na gestão.

Apesar de $60 \%$ dos organizadores terem afirmado utilizar algum modelo para o planejamento e desenvolvimento dos festivais, ao relatarem a respeito, somente dois informaram utilizar ferramentas dedicadas, sendo $5 W 2 H$, Plano de Negócios e o aplicativo web Trello, os demais se referiam a ferramentas como Excell, Google Docs e similares. O tempo de desenvolvimento pré-evento variou entre seis meses e dois anos, dependendo da periodicidade do evento em questão. Todos informaram realizar reuniões com o núcleo organizador para escrever os detalhes, dividir as áreas de atuação e grupos de trabalho. Estas reuniões iniciam com uma periodicidade menor e vão aumentando, indo de trimestrais até semanais, na medida que os encaminhamentos e tarefas vão sendo executados através de uma agenda definida a ser cumprida. 
Figura 8 - Dados Planejamento e Desenvolvimento

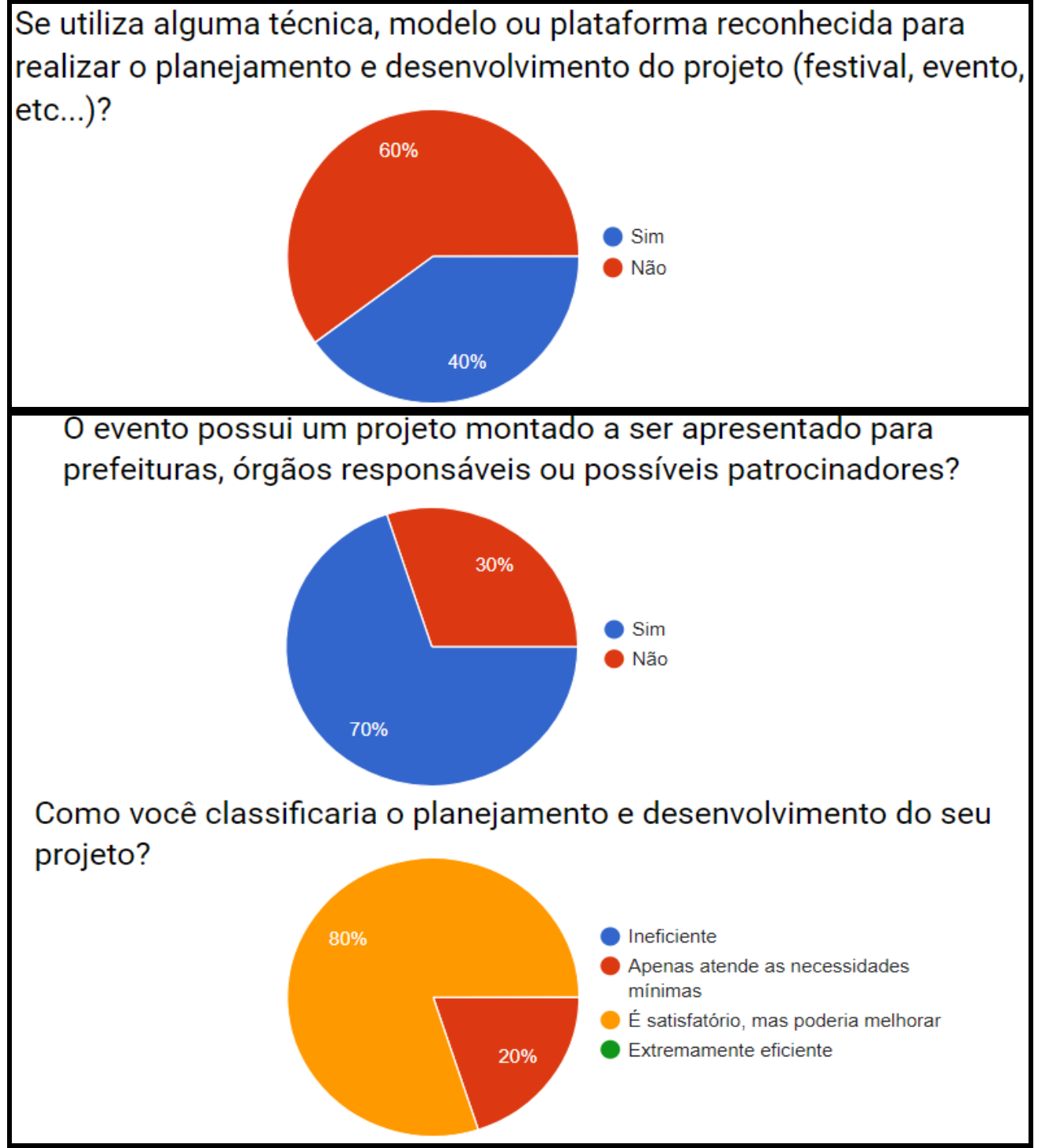

Fonte: Elaborado pelo autor.

Nos festivais acompanhados, foram trabalhados os conceitos de grupos de processos de gerenciamento de projetos, divididos em: Processos de iniciação, processos de execução, processos de monitoramento e controle e processos de encerramento. As atividades e seus respectivos pacotes foram definidas utilizandose decomposição, opinião especializada (dos organizadores) e ondas sucessivas para atualizações futuras que fossem surgindo no decorrer da programação. Todo o planejamento e desenvolvimento, desde a etapa de conceito até a de implementação, foi realizado utilizando como base o modelo de Processo de Desenvolvimento de Serviços proposto por Mello (Figura 3). As atividades eram programadas em formato de agenda aberta, sendo a mesma utilizada para definir datas de encontros e manter atas e registros dos assuntos abordados e decisões tomadas. 
Todas etapas com características mais burocráticas demandaram um esforço dos organizadores para transpor e conectar o conhecimento empírico existente com as ferramentas aplicadas. Apesar de já terem a inteligência de como dividir etapas e tarefas, tiveram que adaptá-lo nos modelos exigidos pelas metodologias. Esta transição foi morosa no início, mas na medida em que foram compreendendo o funcionamento dos mecanismos, a forma como se comunicavam e os seus resultados, vislumbraram as vantagens e benefícios de realizar este esforço para aplicar as ferramentas, metodologias e conceitos envolvidos. Um grande fator motivacional, foi a possibilidade de reaproveitar este material nas próximas edições e utilizar este conhecimento em futuros projetos, além do maior controle e compreensão de todo o evento gerado a partir destas práticas.

\subsection{Projeto e apresentação}

Um dado alarmante que se destaca, trata dos 30\% (Figura 8) que informaram não ter um projeto para ser apresentado às prefeituras, órgãos responsáveis ou possíveis patrocinadores, uma parte importante para buscar apoios e desenvolver diálogos saudáveis e construtivos com agentes públicos das cidades sede. Mesmo assim, ainda foi apontado pelos organizadores como sendo extremamente importante ter um projeto para apresentar.

Os relatos dos organizadores no questionário quanto aos modelos das apresentações foram bem similares, delineando uma estrutura com a descrição do festival, seus objetivos e os benefícios para a cidade sede. Informaram que após a definição do local, seu primeiro passo é entrar em contato com as prefeituras para criar uma relação e diálogo saudável, assim como solicitar a documentação necessária exigida.

Foi desenvolvida, para o festival Beta, uma apresentação e um projeto abrangendo as seguintes informações: O que é o festival, História, Objetivos gerais e específicos, Atrações, Composição do público, Responsabilidade Social e Ambiental, Crescimento econômico da cidade sede, Parcerias, apoios e patrocínios e Documentos exigidos. O festival Alfa já possuía uma apresentação, mas foi remodelada baseada na desenvolvida para o festival Beta acrescentando dados, informações e textos criados a partir dos modelos utilizados no desenvolvimento do 
festival. O festival Alfa também não possuía um projeto para apresentar, o qual foi criado baseado no modelo desenvolvido para o Beta.

Com as apresentações e projetos prontos, foi realizado o seminário entre os organizadores dos festivais Alfa e Beta, mostrando-se uma etapa muito enriquecedora para ambas as partes, pois houve grande troca de experiência, aumento da confiança e domínio dos organizadores nas apresentações e maior robustez no conteúdo informativo dos projetos.

\subsection{Pós-evento}

A questão do pós-evento (Figura 9) trouxe dados interessantes ao apresentar que apenas $5 \%$ utilizam algum modelo para realizar a avaliação através dos organizadores e $20 \%$ através do público. Devido a caracterização dos festivais como um serviço e não um produto, saber a opinião do cliente representa uma parte crucial para seu saudável desenvolvimento, que culminará na fidelização do público. Foi considerado, pelos organizadores, de muita importância realizar uma avaliação do pós-evento através de uma técnica, modelo ou plataforma.

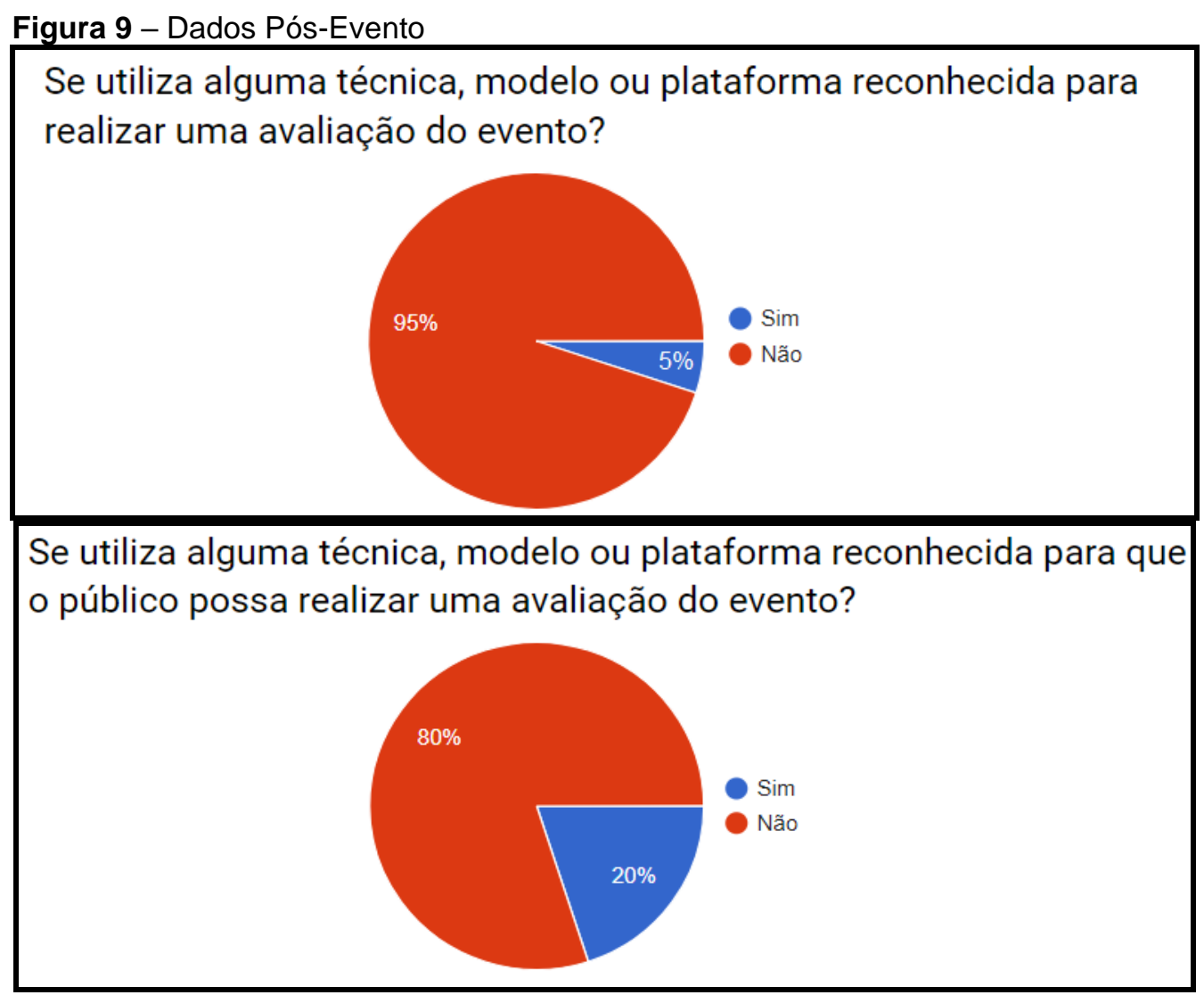

Fonte: Elaborado pelo autor.

Revista Produção Online. Florianópolis, SC, v. 20, n. 4, p. 1088-1125, 2020. 
Os organizadores relataram, no questionário, fazer reunião posterior ao evento, podendo ser feita de uma semana até um mês após, onde são levantadas as impressões de cada área, questões a respeito do local, das atrações e atividades, feedback da equipe e o retorno financeiro de cada setor, com uma atenção especial à venda de ingressos por região. Quanto a opinião do público, foi informado que a mesma é apenas observada através dos comentários nas redes sociais, tendo somente um festival relatado aplicar enquetes e realizar pesquisas de campo.

Dos festivais acompanhados, foram feitas reuniões seguindo um roteiro que passava por todos as áreas, onde seriam levantados os aspectos positivos e negativos, assim como decididas ações para sanar os problemas e dificuldades encontrados. Uma das observações fortemente levantadas pelos membros dos núcleos organizadores, foram as vantagens colhidas através da aplicação das técnicas e ferramentas, seja no pré, durante e pós-evento, aumentado drasticamente a organização e controle de todo festival e suas áreas.

Para que a opinião do público pudesse ser visualizada e quantificada, foi desenvolvido e disponibilizado um questionário on-line, conforme Apêndice $B$, através do qual os participantes puderam repassar suas impressões e sugestões. Alfa e Beta aplicaram o questionário, tendo pela primeira vez coletado oficialmente as opiniões do público referente ao serviço disponibilizado. Os participantes se demonstraram positivamente receptíveis para realizar o preenchimento do questionário, visto a importância que foi dada para a sua opinião. As informações coletadas foram consideradas excelentes pelos organizadores e já estão sendo utilizadas no planejamento e desenvolvimento das próximas edições.

\subsection{Desafios externos e internos}

Através do questionário, os organizadores puderam relatar os principais desafios externos (fatores que não se referem ao núcleo organizador) e internos (fatores que se referem ao núcleo organizador) encontrados no desenvolvimento dos festivais multiculturais.

Dentre os fatores externos, foram apontados a escassez de políticas públicas eficientes capazes de promover e estimular os diversos aspectos da cultura, a falta de apoio das prefeituras e órgãos responsáveis, resistência e preconceito advindo da falta de conhecimento, a dificuldade em captar recursos e verbas, a Revista Produção Online. Florianópolis, SC, v. 20, n. 4, p. 1088-1125, 2020. 
complexidade de encontrar locais e a falta de estrutura nos mesmos (principalmente em eventos urbanos, como ruas e praças), o clima e, finalmente, a conscientização do público nos variados aspectos que tangem os festivais, indo desde a redução de danos, até o alinhamento com os valores praticados e estimulados pelos mesmos.

Dentre os fatores internos, foram apontados como desafios a falta de experiência dos envolvidos, dificuldade em arranjar tempo e disponibilidade, assim como motivação, dedicação e responsabilidade, manter e desenvolver a organização nos processos e a falta de um escritório físico e recursos em geral, mas principalmente financeiros. Um festival é majoritariamente desenvolvido no préevento, ocorre que durante esta etapa todo trabalho executado não possui retorno financeiro algum, sendo um dos principais motivos causais dos desafios internos.

\section{CONCLUSÃO}

Este estudo objetivou identificar as melhores técnicas de gestão de projetos para aplicar no desenvolvimento e aprimoramento de um festival multicultural alternativo sem fins lucrativos. Mesmo já tendo consciência a respeito do cunho exploratório que este trabalho representava, assim como a atmosfera experimental e de aprendizado empírico existente na pesquisa, todas etapas e seus resultados extravasaram positivamente as prospecções iniciais teorizadas.

Além da área de eventos já possuir um cunho mais informal, os festivais da contracultura não possuem muitos estudos ou informações disponíveis para consulta, o que se apresentou inicialmente como um grande obstáculo a ser superado. Realizar a pesquisa de forma isolada, apenas com os festivais acompanhados não traria material suficiente capaz de validar os resultados, assim, a estratégia do questionário direcionado aos organizadores se demonstrou extremamente eficaz para visualizar, delinear, compreender e oficializar os dados e similaridades deste nicho, a forma como se organiza, suas dificuldades, intenções, desejos e oportunidades de melhorias.

Uma vez que foi criada uma imagem com representação relativamente fiel dos festivais multiculturais Brasileiros, a imersão realizada no desenvolvimento dos festivais Alfa e Beta pode ser feita pensando não apenas exclusivamente em ambos, mas sim de uma forma mais global e abrangente, o que possibilitou aumentar a 
qualidade da pesquisa e seus resultados. A carga de aprendizado prático advinda do acompanhamento, aliada ao embasamento teórico construído através do questionário foram muito satisfatórias e definitivas para atingir o objetivo desejado.

O conjunto final de ferramentas aplicadas ficou sendo de realizar a criação do festival baseado no Modelo de Processo de Desenvolvimento de Serviços (Figura 3), dividindo as tarefas através de Decomposição, Opinião Especializada e Ondas Sucessivas, para então alocá-las nos Grupos de Processos de Gerenciamento de Projetos (Figura 1), realizando a estimativa de custos através da Estimativa bottomup, Estimativa de três pontos e Análise de reservas. A gestão dos recursos humanos sendo feita por Papéis e Responsabilidades, Gráficos Matriciais e Organograma. A apresentação e projeto abrangendo: O que é o festival, História, Objetivos gerais e específicos, Atrações, Composição do público, Responsabilidade Social e Ambiental, Crescimento econômico da cidade sede, Parcerias, apoios e patrocínios e Documentos exigidos. Realizar um questionário para colher a opinião do público no pós-evento. Finalizando por estar sempre seguindo os valores e conceitos de uma empresa-cidadã, através das dimensões da sustentabilidade e atuando com os ideais do empreendedorismo social e ecológico.

Apesar de haverem barreiras iniciais para a implementação das ferramentas, através de uma abordagem progressiva, trabalhando os conceitos de forma teórica e prática, foi possível despertar a curiosidade e o desejo nos organizadores de aplicarem e se aprofundarem nas metodologias. A ferramenta era apresentada, contextualizada e demonstrada, para que então os organizadores pudessem contribuir com sua visão e impressão da mesma. Através deste processo, foi possível modelar as técnicas, adaptando-as para sua condição sem que perdessem os efeitos positivos advindos da aplicação. Este procedimento foi responsável por desenvolver uma alta autonomia nos organizadores quanto a utilização das ferramentas, pois os mesmos, além de compreenderem as partes teóricas e práticas, avançaram um passo além, realizando a transformação e adaptação para um formato mais atrativo, prático e condizente com a sua realidade aplicada.

Este nicho de eventos da contracultura ainda enfrenta muitas barreiras nas esferas políticas e sociais, na medida que o preconceito com o diferente ainda guia grande parte das relações existentes em nossa sociedade. Enquanto esta simples, mas enorme barreira não for transposta, todas as formas de expressão artística e cultural autênticas de nossa nação estarão sob constante ameaça de desaparecem Revista Produção Online. Florianópolis, SC, v. 20, n. 4, p. 1088-1125, 2020. 
em meio a enxurrada de conteúdo superficial, amplamente disponibilizado e apenas destinado a comercialização, nos dias atuais.

Um grande fator motivacional para os organizadores dos festivais acompanhados, foi a possibilidade de reaproveitar todo este material nas próximas edições e utilizar este conhecimento em futuros projetos, além do maior controle e compreensão de todo o evento gerado a partir desta experiência. Sendo assim, sugere-se, para o futuro, expandir esta pesquisa com o objetivo de desenvolver um modelo base padrão, composto de técnicas, ferramentas e metodologias, para permitir ampla aplicação no desenvolvimento de festivais multiculturais alternativos sem fins lucrativos.

\section{REFERÊNCIAS}

ABEOC. Disponível em: http://www.abeoc.org.br. Acesso em: 20 mar. 2016.

ABRAFESTA. Disponível em: http://www.abrafesta.com.br. Acesso em: 20 mar. 2016.

ALBUQUERQUE, José de Lima et al. (Org.) Gestão ambiental e responsabilidade social: conceitos, ferramentas e aplicações. 1. ed. São Paulo: Atlas, 2009. 326p.

CLEMENTE, Ademir (Org.) et al. Projetos empresariais e públicos. 3 ed. São Paulo: Atlas, 2008. 344p.

COOK, David P.; GOH, Chon-Huat; CHUNG, Chen H. Service typologies: A state of the art survey. Production and Operations Management. USA, v. 8, n. 3, p. 318338, 1999. https://doi.org/10.1111/j.1937-5956.1999.tb00311.x

CULTURA VIVA. Disponível em: http://www.culturaviva.gov.br. Acesso em: 17 mar. 2016.

DICIO. Dicionário Online de Português. Disponível em: https://www.dicio.com.br. Acesso em: 09 abr. 2016.

GLOBAL REPORTING INITIATIVE. Diretrizes para relatório de sustentabilidade. 2009. Disponível em: http://www.globalreporting.org. Acesso em: 05 maio 2016.

IOSCHPE, Evelyn Berg. 3 Setor: desenvolvimento social sustentado. 2 ed. São Paulo: Paz e Terra, 2000. 173p.

MELLO, Carlos Henrique Pereira et al. Gestão do processo de desenvolvimento de serviços. São Paulo: Atlas, 2010. 194p. 
MARTINS, Jose Carlos. Gerenciando projetos de desenvolvimento de software com PMI, RUP e UML. Rio de Janeiro: Brasport, 2007. 356p.

MINISTÉRIO DA CULTURA. Apoio a projetos. Disponível em:

http://www.cultura.gov.br/apoio-a-projetos. Acesso em: 05 abr. 2016.

PMI - PROJECT MANAGEMENTE INSTITUITE. Guia PMBOK. 5 ed. Pensilvânia, USA: PMI Publications, 2013. 589p.

SACHS, Ignacy. Estratégias de Transição para o Século XXI: desenvolvimento e meio ambiente. São Paulo: Studio Nobel, 1993. 103p.

SEBRAE. O que é ser empreendedor. 2016. Disponível em:

http://www.sebrae.com.br/sites/PortalSebrae/bis/o-que-e-ser-

empreendedor, ad17080a3e107410VgnVCM1000003b74010aRCRD. Acesso em: 22 abr. 2016.

SILVESTRO, L.; FITZGERALD, L.; JOHNSTON, R. Towards a classification of service process. International Journal of Service Industry Management. USA, v. 19, n. 4, p. 399-420, 1992.

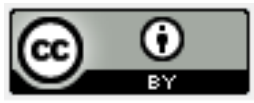

Artigo recebido em: 04/06/2020 e aceito para publicação em: 14/09/2020

DOI: http://dx.doi.org/10.14488/1676-1901.v20i4.3270 


\section{APÊNDICE A}

Figura 10 - Questionário: Informações Básicas

Questionário TCC-II Eng. Prod. APLICAÇÃO DE TÉCNICAS DE GESTÃO DE PROJETOS NO DESENVOLVIMENTO E APRIMORAMENTO DE UM FESTIVAL MULTICULTURAL ALTERNATIVO SEM FINS LUCRATIVOS - Organizador

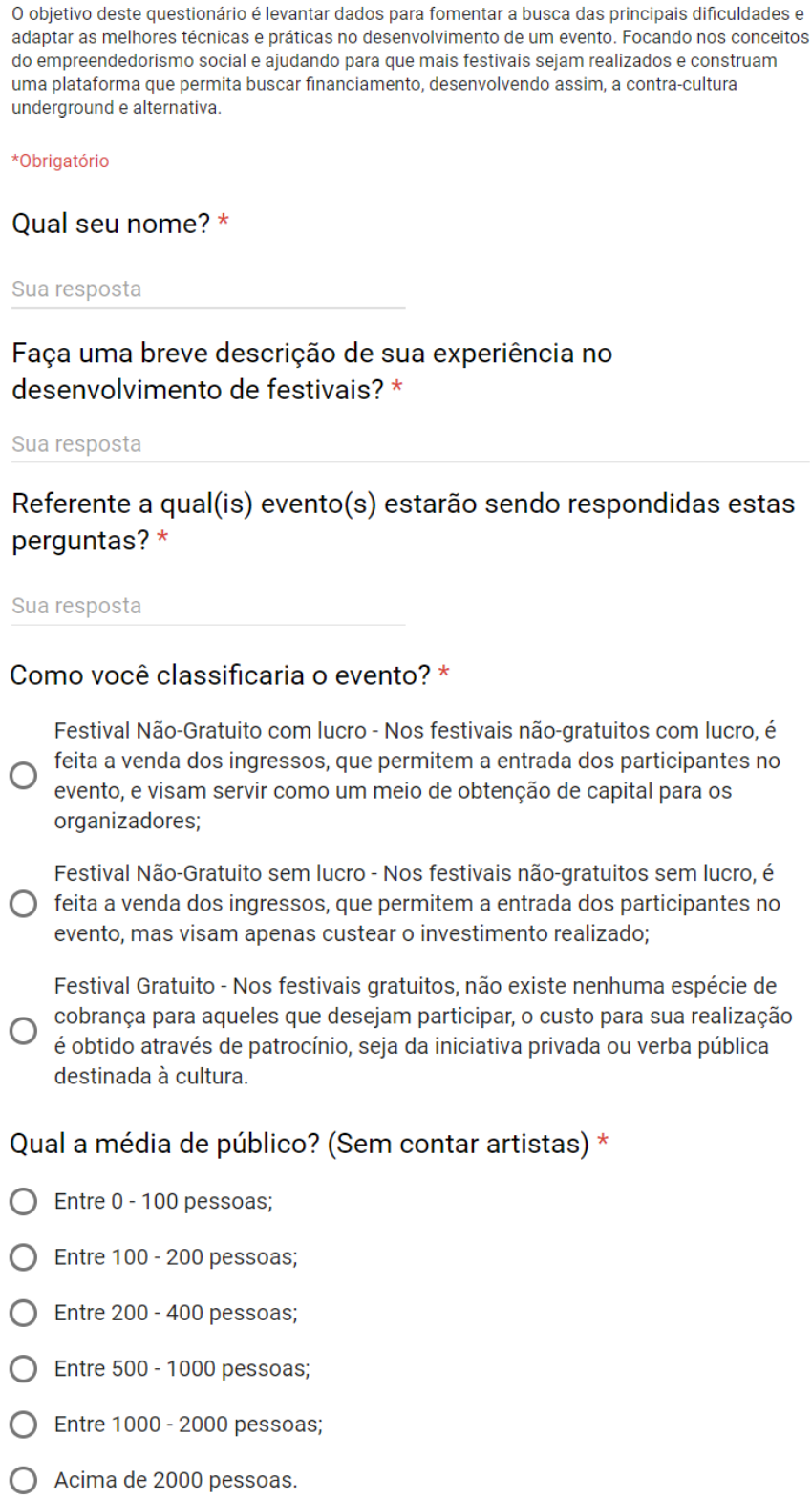

Fonte: Elaborado pelo autor. 
Figura 11 - Questionário: Recursos Humanos

\section{Recursos Humanos}

Esta seção refere-se a área de gestão dos recursos humanos envolvidos no projeto.

Se utiliza alguma técnica ou modelo reconhecido para gestão de recursos humanos? *

$\bigcirc \operatorname{sim}$

Não

Caso a resposta acima tenha sido sim, favor informar o nome desta técnica ou modelo:

Sua resposta

Existe alguma divisão específica de cargos com funções, responsabilidades, competências e nível de autoridade? *

Sim

กล̃o

Caso a resposta acima tenha sido sim, favor descrever, de forma sucinta, como funciona e como é registrada esta divisão:

Sua resposta

Antes do desenvolvimento do festival, são planejados, de alguma forma, os recursos humanos necessários? *

$\bigcirc \operatorname{sim}$

Não

Caso a resposta acima tenha sido sim, favor descrever, de forma sucinta, como é feito este planejamento:

Sua resposta

Como você classificaria a frequência de imprevistos que ocorrem na gestão dos recursos humanos? *

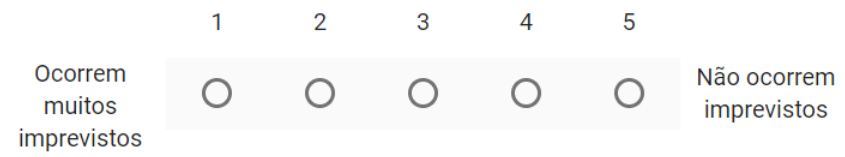

Como você classificaria a gestão dos recursos humanos no seu projeto? *

Ineficiente

Apenas atende as necessidades mínimas

É satisfatória, mas poderia melhorar

Extremamente eficiente

Como você classificaria a importância e impacto de realizar uma boa gestão dos recursos humanos através de uma divisão específica de cargos com funções, responsabilidades, competências e nível de autoridade no seu projeto? *
Nem um
pouco
1
2
3
5
importante

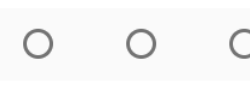
Extramamente importante

Fonte: Elaborado pelo autor.

Revista Produção Online. Florianópolis, SC, v. 20, n. 4, p. 1088-1125, 2020. 
Figura 12 - Questionário: Estimativa de Custos

\section{Estimativa de Custos}

Esta seção refere-se a estimativa de custos envolvidos no projeto.

Se utiliza alguma técnica ou modelo reconhecido para realizar a estimativa de custos? *

$\bigcirc \operatorname{sim}$

Não

Caso a resposta acima tenha sido sim, favor informar o nome desta técnica ou modelo:

\section{Sua resposta}

Como você classificaria o englobamento da estimava de custos do projeto? *

Completa

$\bigcirc$ Parcial

Nula

Caso a resposta acima tenha sido completa ou parcial, favor descrever, de forma sucinta, como funciona, quais áreas são contempladas e como é registrada esta estimativa:

Sua resposta

Como você classificaria a frequência de imprevistos que ocorrem na estimativa de custos? *

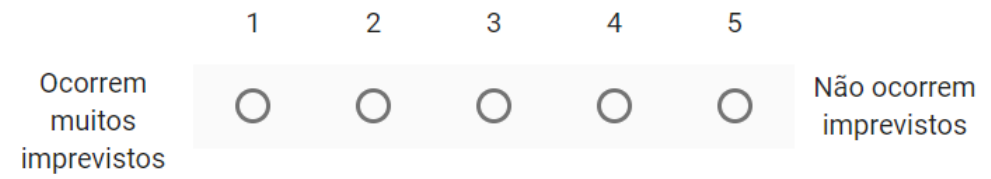

Como você classificaria a estimativa de custos no seu projeto? *

Ineficiente

Apenas atende as necessidades mínimas

É satisfatória, mas poderia melhorar

Extremamente eficiente

Como você classificaria a importância e impacto de realizar uma boa estimativa de custos através de uma técnica ou modelo de reconhecida eficácia no seu projeto? *

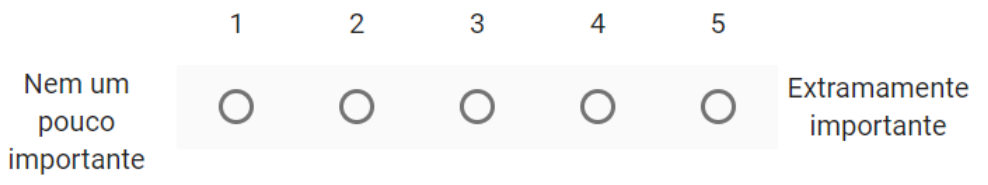

Fonte: Elaborado pelo autor.

Revista Produção Online. Florianópolis, SC, v. 20, n. 4, p. 1088-1125, 2020. 
Figura 13 - Questionário: Planejamento e Desenvolvimento Planejamento e Desenvolvimento

Esta seção refere-se ao planejamento e desenvolvimento do projeto.

Se utiliza alguma técnica, modelo ou plataforma reconhecida para realizar o planejamento e desenvolvimento do projeto (festival, evento, etc...)? *

$\bigcirc \operatorname{sim}$

○ Não

Caso a resposta acima tenha sido sim, favor informar o nome desta técnica, modelo ou plataforma:

Sua resposta

Descreva de forma sucinta, de que maneira é planejado e desenvolvido o festival antes da sua realização: *

Sua resposta

O evento possui um projeto montado a ser apresentado para prefeituras, órgãos responsáveis ou possíveis patrocinadores? *

O sim

ก Não

Caso a resposta acima tenha sido sim, favor descrever, de forma sucinta o formato em que está e é apresentado este projeto:

Sua resposta

Como você classificaria a frequência de imprevistos que ocorrem no planejamento do evento? *

$\begin{array}{ccccccc}\begin{array}{c}1 \\ \text { Ocorrem } \\ \text { muitos } \\ \text { imprevistos }\end{array} & \bigcirc & \bigcirc & \bigcirc & \bigcirc & \bigcirc & \begin{array}{c}\text { Não ocorrem } \\ \text { imprevistos }\end{array} \\ & & & & & & \end{array}$

Como você classificaria o planejamento e desenvolvimento do seu projeto? *

Ineficiente

Apenas atende as necessidades mínimas

É satisfatório, mas poderia melhorar

Extremamente eficiente

Como você classificaria a importância e impacto de realizar um bom projeto para apresentar as prefeituras, órgãos responsáveis ou possíveis patrocinadores? *

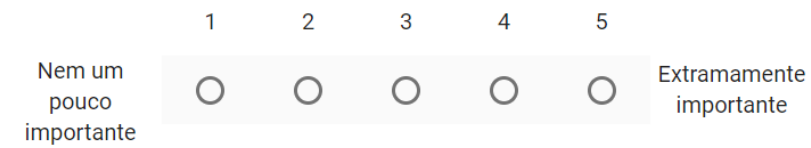

Como você classificaria a importância e impacto de realizar o planejamento e desenvolvimento do evento através de uma técnica, modelo ou plataforma reconhecida? *

\begin{tabular}{|c|c|c|c|c|c|c|}
\hline & 1 & 2 & 3 & 4 & 5 & \\
\hline $\begin{array}{c}\text { Nem um } \\
\text { pouco }\end{array}$ & 0 & & 0 & 0 & 0 & $\begin{array}{l}\text { Extramamente } \\
\text { importante }\end{array}$ \\
\hline
\end{tabular}

Fonte: Elaborado pelo autor. 
Figura 14 - Questionário: Pós-evento

Pós-evento

Esta seção refere-se ao período posterior do evento.

Se utiliza alguma técnica, modelo ou plataforma reconhecida para realizar uma avaliação do evento? *

Sim

Não

Caso a resposta acima tenha sido sim, favor informar o nome desta técnica, modelo ou plataforma:

Sua resposta

Descreva de forma sucinta, de que forma é feita esta avaliação do evento e como são utilizados estes dados no desenvolvimento da próxima edição:

Sua resposta

Se utiliza alguma técnica, modelo ou plataforma reconhecida para que o público possa realizar uma avaliação do evento? *

Sim

Não

Caso a resposta acima tenha sido sim, favor informar o nome desta técnica, modelo ou plataforma:

Sua resposta

Descreva de forma sucinta, de que forma é feita esta avaliação do evento pelo público e como são utilizados estes dados no desenvolvimento da próxima edição:

Sua resposta

Como você classificaria o nível de reaproveitamento de todo material (arquivos, modelos, etc...) criado para o próximo evento? *

$$
\begin{array}{ccccccc} 
& 1 & 2 & 3 & 4 & 5 & \\
\begin{array}{c}
\text { Não se } \\
\text { reaproveita } \\
\text { nada }
\end{array} & \bigcirc & \bigcirc & \bigcirc & \bigcirc & \bigcirc & \begin{array}{c}
\text { Reaproveita- } \\
\text { se tudo }
\end{array} \\
& & & & & &
\end{array}
$$

Como você classificaria o planejamento e desenvolvimento do seu projeto? *

Ineficiente

Apenas atende as necessidades mínimas

É satisfatório, mas poderia melhorar

Extremamente eficiente

Como você classificaria a importância e impacto de realizar uma boa avaliação do evento utilizando uma técnica, modelo ou plataforma reconhecida? *

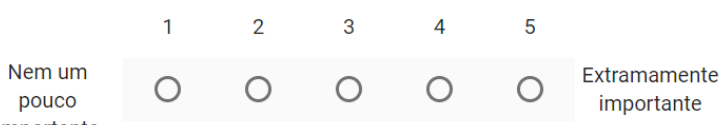

$$
\begin{aligned}
& \text { importante }
\end{aligned}
$$

Como você classificaria a importância e impacto de realizar uma boa avaliação do evento pelo público utilizando uma técnica, modelo ou plataforma reconhecida ? *

$\begin{array}{lllllll}\underset{\substack{\text { Nem um } \\ \text { pouco } \\ \text { importante }}}{1} & \bigcirc & \bigcirc & \bigcirc & \bigcirc & \bigcirc & \begin{array}{c}\text { Extramamente } \\ \text { importante }\end{array} \\ & & & & & & \end{array}$

Fonte: Elaborado pelo autor.

Revista Produção Online. Florianópolis, SC, v. 20, n. 4, p. 1088-1125, 2020. 
Figura 15 - Questionário: Perguntas Finais

\section{Perguntas finais}

$\mathrm{Na}$ sua opinião, quais são os maiores desafios externos no desenvolvimento de um evento? (Entenda-se por desafios externos os fatores que não referem-se ao núcleo organizador. Ex: Políticas públicas, preconceitos e etc.) *

Sua resposta

Na sua opinião, quais são os maiores desafios internos no desenvolvimento de um evento? (Entenda-se por desafios internos os fatores que referem-se ao núcleo organizador. Ex: Motivação, experiência e etc.) *

Sua resposta

Você teria interesse em experimentar utilizar alguma técnica, modelo ou plataforma de gestão de projetos no desenvolvimento ou aprimoramento do evento? *

$\bigcirc \operatorname{sim}$

Não

Justifique a sua escolha: *

Sua resposta

Fonte: Elaborado pelo autor. 


\section{APÊNDICE B}

Figura 16 - Questionário pós-evento

Como você classifica o Line-Up do Palco principal? *

$\begin{array}{lllll}1 & 2 & 3 & 4 & 5\end{array}$

Muito ruim $\bigcirc \bigcirc$ Muito Bom

Caso possua alguma sugestão ou observação escreva aqui:

Como você classifica o Line-Up do Chill Out? *

$\begin{array}{lllll}1 & 2 & 3 & 4 & 5\end{array}$

Muito ruim $\bigcirc \bigcirc \bigcirc \bigcirc$ Muito Bom

Caso possua alguma sugestão ou observação escreva aqui:

Como você classifica o Bar (bebidas)? *

$$
\begin{array}{lllll}
1 & 2 & 3 & 4 & 5
\end{array}
$$

Muito ruim Muito Bom

Caso possua alguma sugestão ou observação escreva aqui:

Como você classifica o Bar (comidas)? *

$$
\begin{array}{lllll}
1 & 2 & 3 & 4 & 5
\end{array}
$$

Muito ruim $\bigcirc \bigcirc \bigcirc$ Muito Bom

Caso possua alguma sugestão ou observação escreva aqui:

Como você classifica a decoração? *

$$
\begin{array}{lllll}
1 & 2 & 3 & 4 & 5
\end{array}
$$$$
\text { Muito ruim } \bigcirc \bigcirc \bigcirc \text { Muito Bom }
$$

Caso possua alguma sugestão ou observação escreva aqui:
Como você classifica as atividades desenvolvidas?*

$$
\begin{array}{lllll}
1 & 2 & 3 & 4 & 5
\end{array}
$$

Muito ruim $\bigcirc \bigcirc \bigcirc \bigcirc$ Muito Bom

Caso possua alguma sugestão ou observação escreva aqui:

Como você classifica a estrutura? (instalações, camping, banheiros) *

$$
\begin{array}{lllll}
1 & 2 & 3 & 4 & 5
\end{array}
$$

Muito ruim $\bigcirc \bigcirc$ Muito Bom

Caso possua alguma sugestão ou observação escreva aqui:

Como você classifica o atendimento recebido na portaria e bar? *

$$
\begin{array}{lllll}
1 & 2 & 3 & 4 & 5
\end{array}
$$

Muito ruim $\bigcirc$ Muito Bom

Caso possua alguma sugestão ou observação escreva aqui:

Como você classifica a celebração como um todo?

$$
\begin{array}{lllll}
1 & 2 & 3 & 4 & 5
\end{array}
$$

Muito ruim $\bigcirc \bigcirc \bigcirc$ Muito Bom

Caso possua alguma sugestão ou observação escreva aqui:

que você definitivamente não gostou? *

que você gostaria que não mudasse? *

O que você gostaria que houvesse na próxima edição?

Fonte: Elaborado pelo autor. 